\title{
INDIGENOUS POLITICAL JOURNALISM IN THE NORWEGIAN AND SWEDISH PUBLIC SERVICE BROADCASTERS
}

Across the world, Indigenous peoples are reclaiming their cultural and political identities, after having suffered decades of assimilation, repression and marginalisation. A major tool in this process is Indigenous journalism, which allows for storytelling and news reporting from the inside, as opposed to being a marginalised group that is only reported about from the outside. This article presents a comparative analysis of Indigenous political journalism as practised in the Norwegian and Swedish public broadcasters. The article explains the differences between the practices of NRK Sápmi and SR Sameradion \& SVT Sápmi regarding their reporting on the campaign leading up to the Sámediggi elections in Norway and Sweden in 2013. The analysis shows that Sámi journalists on both sides of the border adhere to commonly shared characteristics of Indigenous journalism practices, but with considerable variation between them. There are two main conclusions of the analysis. First, NRK Sápmi and SR Sameradion \& SVT Sápmi indeed practise Indigenous journalism, but do so differently, and second, ethnic identity counts, but institutions decide. Sámi journalism is constrained not only by national borders but also by the institutional framework of the parent company, the public service remits and the resources available to them.

\section{KEYWORDS}

Indigenous political journalism, Sámi, NRK Sápmi, SR Sameradion \& SVT Sápmi, Sámediggi election campaigns, Norway, Sweden 


\section{Introduction}

Across the world, Indigenous peoples are reclaiming their cultural and political influences after having suffered decades of assimilation and repression. A major tool in these efforts is Indigenous journalism, which allows for storytelling and news reporting from the inside, as opposed to being a marginalised group that is always reported about from the outside. Recently, studies have pointed to a set of characteristics that seem to unite journalistic practices termed Indigenous (Hanusch 2014; Hokowithu 2013, ch. 6). In the Nordic countries, public service broadcasters have for decades had Indigenous - that is, Sámi - newsrooms, thus providing a test case for the practice of Indigenous journalism. Of particular interest is the fact that Sámi journalism is performed both within and across state and institutional borders, which poses particular problems, on which this article will reflect.

The Sámi people are an Indigenous population of northern Europe, who are citizens of four countries - namely, Norway, Sweden, Finland and Russia - and who are minorities in these states and in their historical homeland, Sápmi (Fig. 1). All of these countries have historically had policies of cultural assimilation and territorial colonisation that have caused a collective loss of language and history as well as racism and discrimination. Today, there is no definitive knowledge of the size of the Sámi populations in Nordic countries. Public registration of ethnicity is prohibited in Sweden and Norway, while in Finland, the definition of who is Sámi is highly controversial. This has resulted in absent and deficient demographic data on the Sámi population. Most sources estimate that 40,000 Sámi reside in Norway, 20,000 in Sweden, 7,500 in Finland and 2,000 in Russia; however, the figures vary and are highly inexact (Lehtola 2004; Pettersen 2014). In Norway and Sweden, the electoral rolls include Sámi people over 18 years old, who have registered to vote in the Sámediggi elections (Josefsen, Mörkenstam, and Saglie 2015). In 2017, the electoral rolls included 8,751 voters in Sweden and 16,958 in Norway. The numbers of registered voters are increasing every year and the electoral rolls cannot be taken as a register of all adult Sámi. According to estimates, about one in three Sámi people speak one of the Sámi languages, but these figures may also be unreliable, with the figures potentially rising as more people start speaking the Sámi languages.

This study includes Norway and Sweden. With a few local exceptions, the Sámi live in rural and urban localities alongside non-Sámi Norwegian and Swedish people within and outside Sápmi. As such, the Sámi community exists on and across the two states. Over the past few decades, Sámi culture, language and ways of living have partly been restored and protected by legislation. New Sámi political institutions - most importantly, the Sámediggi (the Sámi Parliaments) - have been established. The Sámediggi have representative, decision-making and administrative functions, and is popularly elected by and amongst Sámi voters registered on the electoral rolls (Falch, Selle, and Strømsnes 2016; Lantto and Mörkenstam 2015).

The journalistic coverage of the election campaigns prior to the Sámediggi elections is an important source for research on Sámi political journalism. With its starting point in Indigenous journalism, the aim of this study was to answer the following question: Can we identify a particular Indigenous - that is, Sámi - political journalism practice? If so, are there differences in these practices across states? This article explains differences between the practices of the two largest Sámi editorial teams - those in the public broadcasters in Norway and Sweden, the Norwegian NRK and its Swedish counterparts, Sveriges Television (SVT) and Sveriges Radio (SR). The two Sámi editorial teams are NRK Sápmi and SR Sameradion \& SVT Sápmi, respectively. The study relied on document analysis and 
interviews conducted during the period of the election campaigns prior to the Sámediggi elections in Sweden in May 2013 and in Norway in September 2013. For the first time, these two elections and the preceding election campaigns were compared in studies involving parties, voters and the media (Josefsen et al. 2017). The latest Sámediggi elections were in Sweden in May 2017 and in Norway in September 2017. The findings from this study have led to a knowledge base and new hypotheses guiding research on these recent events.

\section{FIG. 1 APPROXIMATELY HERE}

Sámi institutions, politics and journalism in Norway and Sweden

At the state level, the political systems in Norway and Sweden are quite similar: two small Nordic welfare states displaying characteristics of social equality, comprehensive public services and inclusion. The parliamentary party system can be described as multiparty, with most, but not all, parties distributed along the left-right continuum. Both are well-established democracies with many instruments set up to protect, include and culturally sustain minorities and maintain diversity. The state-level media systems are most similar with strong public broadcasters, high newspaper readership and ubiquitous Internet and mobile penetration, a category which has been described as "democratic-corporatist" (Hallin and Mancini 2004) and "welfare state media" (Syvertsen et al. 2014).

At the institutional level, the two countries are somewhat less similar. The Sámi have a constitutional position as an Indigenous people in both countries, but the measures for political influence towards the government and scope of self-determination differ. The Sámediggi in Norway and Sweden share similarities in their dual functions of being both administrative and decision-making bodies but have different competencies and decisionmaking powers. In Norway, the Sámediggi has consultative powers towards the Norwegian government, whereas the Sámediggi in Sweden has less extensive influence (Josefsen, Mörkenstam, and Saglie 2015). In Norway, the Sámi Act states that the Sámediggi decides what matters it considers relevant, while the Swedish Sámediggi has two functions - to be a Sámi representative body and an agency subject to the Swedish government's instructions. The Sámi electoral systems are similar in some respects, and different in others. The members of the Sámediggi are elected for four-year periods in both countries. In Norway, these periods coincide with the periods of the Norwegian parliament, Stortinget. In Sweden, the four-year intervals of the Sámediggi elections are not parallel to those of the parliament, Riksdagen. The constituencies for the Sámediggi elections differ from the constituencies for the national and local governments in each country, and also between the two states. In Norway, representatives of the Sámediggi are elected in seven constituencies; in Sweden, in one only. The constituencies are not limited to the historical Sámi homelands, Sápmi; they cover each country in its entirety. Furthermore, the party systems differ within and between the states. In Norway, Sámediggi MPs are elected from a variety of lists combining parties seeking representation in government at the local and national levels and parties only running for the Sámediggi election. In Sweden, Sámediggi MPs so far were elected from parties unique to Sámi politics. These different and complex institutional arrangements have implications for political reporting for transnational Sámi audiences.

The Sámi media landscape shows corresponding variations. In Norway, two daily Sámi newspapers are supported through the press subsidy system. One is published mainly in Norwegian, the other in Sámi, and both contain extensive political journalism. In Sweden, a monthly Sámi magazine reports Sámi politics, mainly in Swedish (Gottardis 2016). Both 
countries have public service broadcasters that have as part of their remits a particular responsibility to provide media services for the Sámi and have, as mentioned above, Sámi editorial teams that broadcast nationally on a daily basis, on the radio, television and Internet, and in multiple languages (Norwegian/Swedish/several Sámi languages), and journalistic resources to produce continuous news and political journalism. The Sámi divisions of the public broadcasters, thus, have unique positions, with nationwide coverage and the potential to reach most Sámi citizens. This makes up the political and institutional context for Indigenous political journalism and election reporting in the two countries.

\section{Literature review: Indigenous journalism as theory and practice}

Journalism can be defined as a practice whereby information about current relations of public interest is collected, processed and disseminated with a certain requirement for truth and relevance (Eide 2011). Journalism is also a social institution and a necessary component of a democracy that reports on and shapes the public domain around powerful interests (Schudson 2008). For political organisations and actors, the media have many functions, including as regulators of powerful interests, sources of information for the people and as arenas where parties, organisations and politicians meet each other as well as voters for public debate and discussion. The media's dissemination, reporting and production of political news and media content are also of importance for Sámi organisations and voters. Political journalism centres on events, processes, actors and institutions that concern governance and the distribution of power and influence in society. As Plaut (2017) recently argued, as did Anderson (2006) previously, in his modern classic on 'imagined communities', journalism has been and may continue to be an instrument for nation-building. To this, we would add state-building, cultivating cultural and political images and forging ties across territories. In a study of Sámi and Romani journalists, Plaut found that Sámi journalism should indeed be considered 'transnational' journalism, as it seeks to identify and foster a common sense of identity and nation-building across state borders. This line of thought emphasises Indigenous media as an instrument for advocacy and cultural revitalisation. Empirically, it is rooted in the practices and ideological conviction often expressed by Indigenous media producers, which has been

quoted in the studies above and also been criticised. Tara Ross (2017), from the perspective of audience analysis, argued that media consumers have many more reasons for using media than ethnicity. The essentialism implicit in the focus on ethnic media may lead to overlooking audiences, and equally important is the fact that ethnic media are often under-resourced and cannot provide their audiences with a full-scale media menu, as Tom Moring (2007) highlighted. Similar arguments have been made by the authors of this article when assessing the Sámi mediascape and analysing Sámi voters' consumption of political news (Josefsen et al. 2017, ch. 5).

The discussion of Indigenous media and ethnicity always raises the question of how to manoeuvre between the importance of recognising difference and the pitfalls of essentialism, as Ella Shohat (Shohat 1998) noted two decades ago. McCallum and Waller (2017) outlined the strong and long strand of critical studies on race, media and (post)colonialism and placed current Australian research on Indigenous journalism in this context. Māori scholar Brendan Hokowhitu discussed Indigenous journalism from a critical perspective and rejected the notion that it should be conceptualised as a practice and institution distinct from journalism as such or having inherently emancipatory characteristics. Rather, we should approach the field as one of "hybridity and appropriation" - that is, acknowledging that Indigenous media will use technology and produce journalism in many different ways. Ultimately, it is not a specific practice with recognisable characteristics that will define it but the "will, freedom and 
responsibility to represent oneself as they [Indigenous media producers and journalists] see fit" (Hokowithu 2013, Kindle edition, loc. 3957). Our take on this is in line with Hokowithu's; we do not expect Indigenous - in this case, Sámi - journalism to be inherently different from mainstream journalism, but we are interested in looking for the traits that set it out as Indigenous.

Combining insights from different perspectives and studies around the world, Folker Hanusch (2013) defined Indigenous journalism as "the production and dissemination of information about contemporary affairs of public interest and importance, by Indigenous peoples for the benefit of Indigenous but also non-Indigenous communities", thereby emphasising that although it is practised in different ways, Indigenous journalism has some common dimensions. The first is drawing attention to, and strengthening, an Indigenous community's culture and society in relation to the majority community. The second, is about the community telling its own stories as a counterweight to stereotypes and directly false representations in dominant media. The third and fourth dimensions relate respectively to linguistic and cultural revitalisation - namely, that journalism and media production shall actively contribute to the strengthening and revitalisation of language and culture. The fifth and final dimension is the surveillance of powerful interests, or the so-called "watch-dog function", which is one of the main tasks of journalism in general. Taken together, these dimensions form a pragmatic and practical framework that allows for recognising the need for Indigenous self-representations and simultaneously acknowledges that the professional norms of journalism are appropriated into an ethnic setting.

Several studies have examined Sámi journalism from all or some of these dimensions. Linguistic revitalisation is an obligation that Sámi journalists continuously emphasise, but this is not necessarily of equal importance for all Sámi media and in all parts of Sápmi. Cultural revitalisation can refer to many different processes, but for Sámi media, it often refers to revitalising Sámi identity, self-awareness and self-government (Plaut 2014). The question of whether Sámi journalism manages to fulfil its function as a watchdog is often posed in public debates. The problem is twofold: on one hand, whether Sámi journalists manage to investigate and monitor national authorities and make Sámi issues visible in the national public sphere, and on the other hand, whether Sámi journalists, who reside and work in small communities, manage to be critical of the authorities and powerful groups in the Sámi community. Whereas the first concern concerns whether Indigenous journalism has the capacity and competence to critically cover national and regional issues and produce content for the Norwegian and Swedish audiences, the second concerns the extent to which they balance their loyalty and their roles as actors for cultural and political revitalisation with their roles as investigators of Sámi power relations. Studies have concluded fairly unanimously that the journalists combine these dimensions and define their roles as serving the Sámi community, investigating power and being part of the Sámi nation-building project (Eira 2015; Markelin and Husband 2013; Pietikäinen 2008; Plaut 2017). It is demanding to provide Sámi media stories for a diverse and fragmented Sámi audience while simultaneously being visible and fairly represented in equally fragmented national public spheres. Such potential role and loyalty conflicts are not isolated to Indigenous contexts; they are well-known, for instance, in local journalism, where "acquaintance and friendship" can come in conflict with professional ideals (Hanusch 2014). As mentioned above, Indigenous journalism should be assessed as an adaptation of professional journalistic practices rather than as a distinct category. We may also discuss the extent to which it is possible to pursue all five dimensions that Hanusch has identified within the same editorial team or at the same time. Another factor rarely touched upon in studies on Indigenous journalism is the relationship between journalism as a practice carried out by 
professional news media, such as the Sámi editorial teams within the public broadcasters, and civic journalism. Social and digital media offer cheap, accessible and easily available platforms for communication and are of increasing importance for the development of journalism. This is possibly particularly so for Indigenous journalism. Nevertheless, these issues need to be developed further outside the framework of this article. For our purpose, we find the Indigenous journalism framework to be a useful tool for analysing the journalistic practices of the Sámi editorial teams within the Norwegian and Swedish public broadcasters, using the critically important Sámediggi elections in 2013 as the context of the study.

\section{Methods and data}

We adopted a modified comparative most-similar-systems design approach to compare journalistic practices across states and institutions. We obtained data from interviews with the editorial teams of NRK Sápmi and SR Sameradion \& SVT Sápmi. Finland was not included in the research on the 2013 Sámediggi elections; consequently, YLE Sápmi, the Sámi division of the Finnish public broadcaster, is not part of this study. The Swedish public service broadcasting system consists of three companies, and there were two Sámi editorial teams in 2013 - SR Sameradion and SVT Sápmi. They cooperated, were co-located and plans to converge them were in place. The editorial teams merged in 2014 under the name SR Sameradion \& SVT Sápmi with one director; however, at the time of the interviews, these were two units with two directors. Group interviews were conducted with the editorial teams in Kiruna (Sweden) in March 2013 and in Oslo and Karasjok (Norway) in May 2013. Concerning the Swedish teams, the directors of both SR Sameradion and SVT Sápmi were included in the group interview with journalists and commentators working on election coverage on both radio and television. The interview took place in SR Sameradion and SVT Sápmi's offices. Six members of the editorials teams participated in some parts or all of the interview. Two of the journalists had offices outside of Kiruna and participated by telephone. Three researchers from the project team participated, one of whom is a bilingual Sámi and Swedish speaker. The group interview was mainly in Swedish. It took about two hours and was structured according to an interview guide but had the form of a conversation between the researchers and the editorial team including those who were in the room and those participating via telephone. The interviews were recorded and transcribed in Swedish and translated to English when quoted.

The same method was employed for NRK Sápmi. The interview took place in the main office in Karasjok and three from the NRK Sápmi editorial team participated, including NRK Sápmi's then director, who had central responsibility for election coverage. Two of the authors interviewed, one of whom understands and speaks Sámi in addition to Norwegian. The interview was carried out mainly in Norwegian and lasted slightly more than one hour. In contrast to Kiruna, journalists who were "out of house" did not participate in the group interview via telephone, but one of the journalists responsible for the election coverage was interviewed in Oslo. These interviews were recorded and transcribed in Norwegian.

All informants were bilingual, mastering both Sámi and the majority language. Owing to the research team's varying linguistic skills, the interviews were carried out in the majority languages. The interviews were analysed as conversations, and citations are collectively assigned to the editorial teams, not to individual participants. This was due to both practical and research ethical considerations. We interviewed the editorial teams as two collectives that were to undertake the task of reporting on the Sámediggi elections in Norway and Sweden in 2013, and the participants discussed and agreed on answers. We did not ask questions about ranking amongst the participants, and we left it to the editorial teams to decide whom they 
wanted to include in the conversation. Further, since the interviews, some of the informants have changed their job status. Therefore, it was of little relevance to refer to individuals. The interviews were thematically analysed and the statements from the editorial teams are systematically compared in this article employing qualitative analysis to discover meaning, similarities and differences between the two teams (Kvale and Brinkmann 2009; Corbin and Strauss 2008).

The interviews gathered information about a range of details, but we also collected data from other sources, primarily in the form of documents accessible on the Internet. They included annual reports, public service broadcasting reports, public service accounting reports and the websites of media organisations, their owners and regulating bodies. The documents were treated as historic sources and analysed with the aim of identifying similarities and differences between how public service broadcasting in general, and Sámi public service broadcasting in particular, is defined and reported in Norway and Sweden (Karppinen and Moe 2012). The quality of these sources varied between the countries, as the Norwegian documents contained many more details on the organisation and production of NRK Sápmi than the Swedish ones did, and, complicating things further, some sources were somewhat contradictory. Consequently, we are unable to provide a detailed comparison between the resources available to each national team. Rather, we make qualified judgements on the basis of the information given in the interviews and documents.

\section{Findings: Indigenous journalistic practices within the public service broadcasters}

The public service broadcasting remit is articulated slightly differently in the two countries. In Norway, the NRK is a state-owned corporation with a license to broadcast that is legally enshrined. The remit is comprehensive and specified in five main points: strengthen democracy; provide universally accessible programmes; strengthen the Norwegian and Sámi languages, identity and culture; strive for quality and innovation; and be non-commercial. In Sweden, three independent companies owned by a managing foundation have public service broadcasting obligations: SVT, SR, and Sveriges Utbildningsradio ${ }^{1}$ (Forvaltningsstiftelsen 2018). They are obliged to produce and broadcast universally accessible programmes for the public. The operations should be characterised by impartiality, integrity and independence both regarding the state and other powerful interests (Sveriges Radios Sändningstillstånd 2014-2019, 1 [transl. 'The Swedish Radio's Broadcasting License']). SR's and SVT's remits include the provision of a multifaceted and broad programme offering with a particular responsibility for the Swedish language. The programme offering is to reflect the whole country and the variety within the population from the perspectives of equality and diversity, and must provide content in the national minority languages of Sámi, Finnish, Meänkieli, Romani chib and Yiddish.

In the following paragraphs, we give an account of how Indigenous political journalism - that is, the reporting of the Sámediggi election campaigns - was conceived of by the Sámi editorial teams of the Norwegian and Swedish public broadcasters, starting with NRK Sápmi.

\section{NRK Sápmi}

Previous studies on NRK Sápmi firmly established that the editorial team prioritises cultural and linguistic revitalisation (Plaut 2014; Skogerbø 2001). NRK Sápmi defines itself as an Indigenous broadcaster, realised through active international cooperation to increase and develop programme exchange, creation and development with other Indigenous stations 
around the world. In 2013, the department had eight district offices - seven in Sámi areas and one in Oslo.

NRK Sápmi expanded its coverage to radio, television and the Internet, and grew from around 40 employees in 1993 to around 100 employees in 2013. Accordingly, the editorial team strengthened its position as the central producer of Sámi journalism. In 1999, nearly 2,000 hours of radio were produced on the FM network. This remained stable until 2013, while programmes on digital radio (DAB) expanded from about 500 to about 6,500 hours during the same period. NRK has its own digital Sámi radio channel, accessible across the country on DAB or Internet radio. Sámi language programmes are also broadcast daily on the NRK P2 network in the North and via a designated broadcaster in the Oslo area. Northern Sámi is the primary language of radio broadcasts, with permanent and recurring inserts in Southern Sámi, Lule Sámi and Norwegian.

The level of television production grew during the same period. In 1999, 36 hours were produced, while the corresponding output in 2013 was 278 hours. TV-Ođđasat was (and in 2018 still is) co-produced by NRK Sápmi, SVT Sápmi and YLE Sápmi. From 2003 onwards, TV-Ođđasat broadcast 15 minutes of news from Finland, Sweden and Norway, five days a week. These news programmes and other Sámi language programmes are subtitled in the majority languages. Sámi news was also available on Internet television and NRK Sápmi produced Norwegian language online news (NRK 2011).

At the time of our data collection and later, NRK Sápmi used Sámi both as the primary broadcasting language and a working language, and the editorial team emphasised that this was a distinct situation as compared to many other Indigenous media (e.g. Hafsteinsson and Bredin 2010):

Other Indigenous broadcasters think that it is unique that we use Sámi as a working language. They often have to serve many Indigenous peoples, and therefore, the majority language often is their only common language. (interview with the editorial team in NRK Sápmi, May 2013)

In their account of the planning of the election campaign reporting, the team pointed out that NRK Sápmi prioritised serving the Sámi voters and was less occupied with the requirement to inform the majority population about the Sámediggi election. The ambition was for NRK's nationwide parliamentary election reporting to include the Sámediggi election, but this was uncertain at the time of the interviews. Previous studies showed that Sámi political issues were increasingly marginalised in nationwide political news during the same period in which the Sámi newsroom grew (Ijäs 2012), indicating that more extensive Sámi political journalism does not necessarily provide access to the national public sphere. This topic has been discussed in analyses of other indigenous media elsewhere (Hokowithu and Devadas 2013). The editorial team had a range of strategic choices to make regarding how and in which language election constituencies, parties, issues and conflicts would be covered and which platforms would be prioritised.

In 2009, most of TV-Ođđasat's coverage of the parallel Sámi and Norwegian parliamentary elections was actually about the Norwegian, not the Sámi, election campaign (Josefsen and Skogerb $\varnothing 2013)$. The editorial team wanted to change this in 2013. As the Norwegian parliament sets the framework for the Sámediggi's operations and power, the plan was to confront Norwegian politicians about Sámi issues. The journalists argued that it was 
important for voters to be provided with information about which Sámi politics the Norwegian parties were adopting and what the top candidates for the national elections stood for: "When it boils down to it, it is the Norwegian parliament that decides. The Sámediggi politicians can want to do a lot, but they don't have the decision-making authority" (interview with NRK Sápmi, May 2013). Thus, it was a conscious decision and concerted effort to cover the Norwegian parliamentary campaign and obtain answers about Sámi political questions that the Norwegian parliament had the authority to deal with, such as the Sámediggi's jurisdiction and the Progressive Party's most important campaign topic, the proposal to abolish the Sámediggi.

Coverage of the election posed a dilemma for NRK Sápmi - namely, to what extent the Sámi language should be used in the reporting on the election (linguistic revitalisation), and whether using Sámi should be prioritised over the objective of reaching all Sámi voters (universality). It was often repeated during the interviews that election debates and news about the election had to be in Sámi, and that this was essential for NRK Sápmi: "The day that NRK Sápmi stops using the Sámi language as much as possible, we might as well disband" (interview with NRK Sápmi, May 2013). The editorial team, thus, weighed the consideration of reaching as many Sámi voters as possible, including those that did not speak a Sámi language, against the consideration that NRK Sápmi was an arena for strengthening and revitalising Sámi culture and languages, and chose the latter (interview with NRK Sápmi May 2013). The dilemma was partly solved by the fact that different technological platforms were complementary and had different primary languages: The Internet was in Norwegian, the radio in Sámi and television multilingual, thus providing services for Sámi- and Norwegianspeaking Sámi citizens and for the majority population.

In the context of election campaign reporting, there are different national regulations regarding how parties shall be covered. In Norway, it is the editorial teams that normally decide whether, when and which candidates get access, and NRK Sápmi followed this practice. The editorial team selected items and interviewees, and no parties could demand coverage: "We decide ourselves which items we are going to produce" (interview with NRK Sápmi, May 2013). Therefore, they adhered to the principles of independent critical political journalism. They sought to set the agenda and not be mouthpieces for politicians. The content analysis revealed that NRK Sápmi indeed achieved this (although the election reporting contained many items that mainly presented both top party candidates and party information) (Josefsen et al. 2017, : ch. 5) . At the same time, the journalists' access to sources was somewhat restrained by language: "When it comes to radio, one of the most important criteria for selecting those who are interviewed is that they can speak Sámi" (interview with NRK Sápmi May 2013). Here, the Sámi journalists chose a different strategy than the most common one in political journalism: chasing the "best sources", or those who are most centrally placed, with access to plenty of exclusive information and who have the most credibility and highest "media capital" (Davis 2010). In keeping with the language criteria, top candidates who were non-Sámi speakers could, if this priority was carried out, risk being excluded from the radio's news and election reporting. The editorial team maintained that complementary platforms, multifaceted coverage and journalistic follow-up prevented this: "If we choose a Sámi-speaking politician, it doesn't mean that all parties don't get to express their opinions (on other platforms)" (interview with NRK Sápmi May 2013).

One element that was not commented on in the interviews is that in 2013, content on the most accessible and most "sharable" platform, the Internet, was principally in Norwegian. Studies on digital media have found that minority languages are used less in digital than in other 
media (Bhroin 2015), and this seemed to be the case for NRK Sápmi in 2013. Since then, the use of Sámi on the website has increased.

\section{SR Sameradion \& SVT Sápmi}

In Sweden, SR Sameradion and SVT Sápmi belong to two different companies - SR and SVT, respectively. They were co-located in Kiruna in 2009, but had different organisations and leadership (Sveriges Radio 2016). In 2014, the two editorial teams were merged into one producing Sámi journalism and other programmes on radio, television and the Internet. Nonetheless, the organisations report to two separate companies and are described by means of introduction as such. SR has, since the mid-1970s, broadcast under the name "Sameradion" (transl. Sámi Radio). Since 2000, it has been organised as a distinct department of SR. In 2013, SR Sameradion had its main editorial team in Kiruna and employees in several localities including the capital, Stockholm, and was broadcasting in several Sámi dialects and Swedish. Approximately two hours of programming were broadcast on weekdays and one hour on Sundays.

SVT Sápmi produced news and other television programmes for and about the Sámi, in line with SVT's obligations with regard to providing a distinct programme offering in Sámi. The news programme Ođđasat (transl. News) has been broadcast since 2001 (Sveriges Radio 2016). Since 2007, it has been broadcast in cooperation with SR Sameradion, NRK Sápmi and YLE Sápmi. In 2013, SVT broadcast 84 hours of Sámi language content (Sveriges Radio 2013: table 4.2,69). The editorial team described its production practices as follows:

We broadcast in four different languages and are part of the creation of Nordic radio and TV broadcasts across three countries. We also have a common Internet platform and text TV as well as the Internet radio SR Sápmi” (interview with the editorial teams of SR Sameradion \& SVT Sápmi, March 2013).

When we interviewed the Sámi editorial teams in March 2013, they had not been formally converged, even though they were co-located and clearly enjoyed good cooperation.

Regarding the question of belonging to two different companies and whether this influenced their strategic choices, they referred to the public service remit: "We receive clear directions from our leadership in Stockholm that we are to be accessible for as many as possible; and even for the Swedish population" (interview with the editorial teams of SR Sameradion \& SVT Sámi, March 2013). The consideration that everyone should be reached (universal coverage), was a theme that prevailed throughout the interviews. "We think that it is very important that we reach as many Sámi as possible" stood out as a proclamation that explained and predicted the journalistic practice. In the balance between universal coverage and language, this also became apparent:

Less than 50 per cent of the Sámi community in Sweden speak or understand Sámi. We won't reach the majority that don't speak Sámi if we broadcast everything in Sámi. Still, the primary language is Northern Sámi, even if we have a lot in Swedish. (interview with the editorial teams of SR Sameradion \& SVT Sápmi, March 2013)

The quotation above explains why SR Sameradion \& SVT Sápmi chose to offer a large portion of Sámi political journalism in Swedish. In 2013, the two large election debates and all interviews with party leaders on the radio were broadcast in the majority language, as was other reporting on the election campaign on radio, television and on the websites. Televised 
news and political journalism and election coverage were produced in Sámi. Furthermore, the editorial teams emphasised that they were the largest Sámi media in Sweden, and that this, in turn, presented them with a substantial responsibility towards their audiences, in particular in terms of reporting the election:

If we don't do this election coverage, who will? There are no others. Of course we have an enormous responsibility. (interview with the editorial teams of SR Sameradion \& SVT Sápmi, March 2013)

The relationship to the Sámi audience was emphasised, and feedback from listeners, readers and viewers in comment sections and on social media was important for the editorial work. Not only did such feedback create ties with the audience, it also allowed opportunities to change and correct mistakes and misinformation. The teams also emphasised that their reporting had to be diverse, critical and accountable: "We are sitting in a monopoly situation. It implies, of course, that there are very high demands for what we report. There is to be diversity in subjects, participants, gender balance and content" (interview with the editorial teams of SR Sameradion \& SVT Sápmi, March 2013).

Further, the editorial teams emphasised storytelling, cultural revitalisation and critical investigation when asked to describe their mission: "We are to investigate what happens in Sápmi, in the Sámi area and within the Sámi community. An important role is to be a part of, and build up, the Sámi community; therefore, investigating is very important (interview with the editorial teams of SR Sameradion \& SVT Sápmi, March 2013). The editorial teams also revealed that the politicians preferred speaking in Swedish in election debates and interviews, and that there were no reactions among party leaders and political candidates to the fact that Swedish was the primary language of the election coverage. On the contrary, politicians were said to choose Swedish over Sámi because they reached more voters by using the majority language, especially when talking in plenary sessions that were broadcast live.

The editorial team did not impose any linguistic constraints on the choice of sources for its election broadcasts and did not mention that it could be difficult to find Sámi-speaking sources for television. According to the interviews, the parties often decided who should participate in broadcast debates, but the editorial team set limitations regarding specific programmes, such as the questioning of party leaders. In other programmes, they sought out specific representatives, but could not control whom the parties chose to send.

During the interviews, it also came to light that language was used differently on the various platforms: "TV broadcasts, which can be subtitled, present different possibilities." Different technical platforms were used complementarily for election reporting, but the rationale for this was related to the need for editorial, rather than linguistic, coordination. The cooperation between Sameradion and SVT Sápmi was built around two joint websites - oddasat.se and sametingsvalet.se - which functioned as navigational anchors to produce news and election content. In addition to news about the election and election campaigns on sametingsvalet.se, it also featured articles from invited bloggers, candidates on party lists, party interviews, party programmes and other information. The objective was to publish as much as possible on the Internet first and subsequently broadcast this content as news on the radio and television: "First on the Internet - sametingsvalet.se or oddasat.se - and after that on radio or TV, or both" (interview with the editorial teams of SR Sameradion \& SVT Sápmi March 2013). Our analysis of the election coverage supports this; that is, most items were published on the 
Internet in addition to being broadcast as news on the radio and television almost exclusively in Swedish (Skogerbø and Vestli 2016).

\section{Discussion: Differences and Explanations}

Now, we return to the research question: Can we identify a particular Indigenous, or rather Sámi, political journalism practice? How can we explain the differences between the two teams? As we noted above, the comparison between Indigenous practices within the public broadcasters in Norway and Sweden reveals similar systems designs. Therefore, it is not the many similarities amongst the Sámi journalistic practices that we seek to explain but the differences as they manifest in relation to the five dimensions set out by Hanusch and referred to above: drawing attention to and strengthening the Indigenous community at large, regardless of where the people live; telling the community's own stories; linguistic revitalisation; cultural revitalisation; and being a watchdog. Further, we highlight how the Indigenous journalistic practices are constrained by their taking place within national public service institutions.

NRK Sápmi and SR Sameradion \& SVT Sápmi occupied vastly different positions in the organisational structure of their respective parent companies. While NRK Sápmi was (and in 2018 still is) a department under the immediate responsibility of the CEO of NRK, SR Sameradion \& SVT Sápmi were (and in 2018 still are) placed lower in the organisational hierarchy amongst several local offices. In 2013, NRK Sápmi had 99 employees, while the corresponding number for SR Sameradion \& SVT Sápmi was between 10 and 20, and budgetary provisions differed accordingly. The parent companies' annual reports also showed corresponding differences. NRK's annual reports detailed NRK Sápmi's operations and programme production, while the Swedish documents did not mention SR Sameradion and SVT Sápmi as organisational units at all. These structural differences were likely to impact the editorial teams' resources and their capacity to highlight the Sámi community in their journalism, both for the Indigenous and majority audiences. There were considerable differences in the resources set up for journalistic production and in the production outcome, measured in hours of television and radio broadcasts. Concerning online production, fewer differences could be observed. As such, the editorial teams in Sweden, which were not only much smaller but also divided between two companies, initially had fewer opportunities to draw attention to the Sámi community. Further, the claim to universality placed on the Sámi editorial teams from the parent companies to produce news and other programmes for the entire Swedish population was clear. In Norway, by 2013, this claim was no longer discussed as a dilemma for Sámi journalism at NRK Sápmi, whereas it was very clearly so in the Swedish context. Not only was it more demanding resource-wise to produce in Sámi, because it usually required translation, subtitling, voiceover and command of the Sámi language, but Sámi-language items were rarely, if ever, aired on nationwide programmes on television and radio. Producing in Sámi, thus, did not meet the public service requirement of serving the entire audience - that is, universality.

The editorial teams in both countries emphasised heavily their responsibility to practise political journalism from the inside. The fact that Sámi stories are rarely told by the mainstream, nationwide media, was the very motivation for doing Sámi political journalism, as voiced in the quotation, "If we don't report, who does?" Our research confirms that the Sámi public broadcasters have the most extensive coverage of Sámi politics and, in Sweden, are the only news media that reported on the Sámediggi election campaign on a regular basis. The situation is somewhat different in Norway, as Sámi and, to some extent, local newspapers 
in northern Norway report regularly on Sámi politics and elections (Josefsen et al. 2017, ch. 6). Both Sámi editorial teams described their practices as Indigenous journalism, while they highlighted and emphasised different dimensions. On both sides of the border, they were acutely aware of their position as the main producer of Sámi political journalism and the main mediated public space for Sámi politics. However, they differed fundamentally in the linguistic design of these spaces. At NRK Sápmi, Sámi politics were mainly reported and published in Sámi, whereas at SR Sameradion \& SVT Sápmi, the Sámediggi election campaign and its actors were largely reported in the majority language, Swedish. This is in contrast to the journalists' Sámi language background, which seemed to have little bearing on the media institutions' strategic choices regarding language use. The marked difference in resources, nevertheless, adds to explaining the difference. By far, NRK Sápmi had more journalists and resources to provide multilingual content, whereas their Swedish sister organisation had to choose.

NRK Sápmi's role in the linguistic revitalisation was clearly stated as one of its raisons d'être. It was more important that the election was covered broadly in Sámi on radio and television than that all Sámi voters could benefit from all the election reporting. At NRK Sápmi, providing coverage and an arena for Sámi political actors in Sámi was all-important, to the degree that sources and representatives of non-Sámi speaking voters could risk being overlooked on one of their platforms - namely, radio. As televised news could be subtitled, this programme would reach the non-Sámi speaking Sámi audience in addition to the broader Norwegian audience. The emphasis on language created a dilemma between providing universal service for the Sámi (and Norwegian) audiences and creating a Sámi-language political space. At Sameradion \& SVT Sápmi, the raison d'être was different; reaching all Sámi voters with relevant investigative journalism was regarded as a means of cultural revitalisation and was more important than contributing to linguistic revitalisation. As televised news in Sámi could be subtitled, they also served the purpose of reaching a multilingual audience. On the Swedish side, universality in reach was all-important, creating an opposite dilemma: the editorial team included a non-Sámi-speaking audience in all election coverage, but lost the potential to create a Sámi-language arena for Sámi politics.

To understand the differences between the journalistic practices and priorities of the Sámi editorial teams regarding language use in radio coverage, we must assess the differences between Norway and Sweden with regard to political history, and particularly the difference between these countries regarding the importance of language as a political differentiator in the state- and nation-building processes. In Norwegian political history, linguistic revitalisation was part of the post-colonial independence movement and one of the central political conflict lines in the Norwegian nation-building process in the late 1800s. Without going into detail, we can identify that the political "solutions" to the language conflict after the Norwegian state was founded in 1905 resulted in the establishment of two equal varieties of the Norwegian language - Bokmål and Nynorsk. Nynorsk has always been a minority language, but it received special protection through its inclusion in official politics. Public institutions, among them NRK, were obliged to use both languages. This happened during the period when the harsh assimilation policies towards the Sámi and other ethnic minorities peaked, but it also likely gave legitimacy to later linguistic demands from these groups. This may be one of many explanations for why Norway commenced Sámi broadcasts relatively early (before the Second World War) and why linguistic revitalisation has been a legitimate purpose in public media policy for a longer time than in Sweden. Sweden has a correspondingly harsh history of assimilation of ethnic minorities, especially since the beginning of the 1900s, although the Swedish state is much older than the Norwegian state 
and has a long history of being multilingual and multicultural. It has included territories populated by many linguistic groups, but linguistic revitalisation did not result in political conflicts in either the state- or nation-building process. According to Kenneth Hyltenstam (1999, 11-12), assimilation and rejection, rather than recognition of linguistic diversity, influenced Swedish nationalism and nation-building.

Then, what about investigative, critical Indigenous journalism? Did the variations between the editorial teams also reflect differences in how critically they investigated and monitored Sámi and other authorities? The data analysis did not provide a clear answer to this question, but the interviews suggested that investigative critical journalism was important to both teams. However, owing to the differences between the two countries' electoral systems, the frameworks within which the two teams produced Sámi political journalism also differed. NRK Sápmi must report two election campaigns simultaneously, as the elections for the Norwegian parliament and the Sámediggi are held on the same day. Therefore, journalists had an opportunity to connect the two campaigns and confront parliamentarian candidates with questions about Sámi issues and thereby give voters information and news about the relations of strength and power between the Norwegian parliament and the Sámediggi. The Sámediggi candidates could be asked to comment on and discuss the views of parliamentarian parties and candidates, creating opportunities for investigative journalism both of the state and Sámi authorities. In Sweden, the election period for the Sámediggi in Sweden did not run concurrently with that of any other governing body, and the journalists did not have the same obvious opportunities to establish connections between different levels of decision-making. These different situations obviously influence the practices of election reporting and political journalism. In Norway, the reporting on Sámediggi elections may be overshadowed by Norwegian parliamentarian elections, and in Sweden, it can be too detached from other political processes. This is a challenge for Sámi political journalism that has relevance far beyond election coverage. Sámi people, regardless of language and whether they use their opportunity to vote in Sámediggi elections, are also residents of municipalities, counties and states, and have political, cultural and social connections beyond the Sámi community. Most of the decisions that affect Sámi citizens are taken at other levels and outside of both the Sámi media's sphere of interest and catchment area. For example, questions relating to the Sámi language and language learning involve decisions in municipalities, counties, the Norwegian/Swedish parliament and the Sámediggi, while other questions of great consequence for the Sámi community, such as climate and environment, are ultimately addressed at the national level or by supranational bodies. In our analysis of the coverage of the 2013 Sámediggi elections, we found this in items that affected the Sámediggi's role in managing land and resources in the Sámi area, where these items are adopted by the Norwegian or Swedish parliament or international bodies.

\section{Conclusion: Identity counts, but institutions decide}

Our analysis yielded two main conclusions. First, the five dimensions of Indigenous journalism can be matched with Sámi political journalism. The editorial teams of NRK Sápmi and SR Sameradion \& SVT Sápmi indeed showed evidence of practising Indigenous journalism, but with some differences. Linguistic revitalisation was more important for NRK, whereas SR Sameradion \& SVT Sápmi put more weight on cultural revitalisation and universal services for the Sámi audience. The second conclusion can be summed up in a rephrasing of Stein Rokkan's famous slogan "votes count, but resources decide" (Rokkan 1966). To explain the differences between Sámi journalism in Norway and Sweden, the analysis showed that ethnic identity counts, but institutions decide. Sámi journalism is constrained not only by limited resources, immense distances and scattered audiences but also 
by the institutional framework of the parent company, the public service remits and the status of the Sámi. The analysis revealed that the editorial teams in both countries only drew to a limited degree on each other's experience; rather, they regarded each organisation as an individual entity. Cross-border journalistic practice was rare, with few traces of focused, goaloriented cooperation beyond the minimum that TV-Ođđasat entails, to develop a joint Sámi political journalism. Where Sámi diversity was promoted as a value, it was within national boundaries and the budgets and remits of the parent companies. As such, Indigenous journalism challenges the public service broadcasting remit: it tells the story of a divided people across borders, where Indigenous journalists must operate within the constraints of both national public service institutions and separate political systems.

\section{NOTES}

1. Sweden's Educational Radio. It does not have its own Sámi editorial team and is excluded from the analysis.

\section{REFERENCES}

Anderson, Benedict. 2006. Imagined communities: reflections on the origin and spread of nationalism. London: Verso.

Bhroin, Niamh Ní. 2015. "Lost in space? Social media-innovation and minority language use." Phd Thesis, University of Oslo, Faculty of Humanities.

Corbin, Juliet M., and Anselm L. Strauss. 2008. Basics of qualitative research: techniques and procedures for developing grounded theory. Thousand Oaks, Calif.: Sage.

Davis, Aeron. 2010. Political Communication and Social Theory. Hoboken: Taylor \& Francis.

Eide, Martin. 2011. Hva er journalistikk? Oslo: Universitetsforl.

Eira, Stine Sand. 2015. "In front of and behind the camera: Media images from Northern Norway." International Journal of Media \& Cultural Politics 11 (3):315-27. doi: 10.1386/macp.11.3.315_1.

Falch, Torvald, Per Selle, and Kristin Strømsnes. 2016. "The Sámi: 25 Years of Indigenous Authority in Norway." Ethnopolitics 15 (1):125-43. doi: 10.1080/17449057.2015.1101846.

Gottardis, Andreas. 2016. "Politikområden, partier og politiske företrädare: En studie av nyhetsbevakningen av sametingsvalet 2013 i tryckt media." In Sametingsval. Väljare, partier och media, edited by Ragnhild Nilsson, Stefan Dahlberg and Ulf Mörkenstam, 269-87. Stockholm: Santérus.

Hafsteinsson, Sigurjón Baldur, and Marian Bredin. 2010. "Indigenous Screen Cultures in Canada." In. Winnipeg: University of Manitoba Press.

Hallin, Daniel C., and Paolo Mancini. 2004. Comparing media systems: three models of media and politics. Cambridge: Cambridge University Press.

Hanusch, Folker. 2013. "Charting a theoretical framework for examining indigenous journalism culture." In Media International Australia incorporating Culture and Policy, 82+.

- - . 2014. "Dimensions of Indigenous journalism culture: Exploring Māori news-making in Aotearoa New Zealand." Journalism 15 (8):951-67. doi: 10.1177/1464884913495757.

Hokowithu, Brendan. 2013. "Theorizing Indigenous Media." In The Fourth Eye. Māori Media in Aotearoa, edited by Brendan Hokowithu and Vijay Devadas. Minneapolis: University of Minnesota Press.

Hokowithu, Brendan, and Vijay Devadas. 2013. "The Fourth Eye. Māori media in Aotearoa." In. Minneapolis: University of Minnesota Press.

Hyltenstam, Kenneth. 1999. "Sveriges sju inhemska språk - ett minoritetsperspektiv." In. Lund: Studentlitteratur. 
ljäs, Arne Johansen. 2012. Samer i to norske nyhetsmedier : en unders $\emptyset$ kelse av saker med samisk hovedfokus i Nordlys og Dagsrevyen i perioden 1970-2000. Vol. 1/2012. Guovdageaidnu [Kautokeino]: Sámi instituhtta.

Josefsen, Eva, Ulf Mörkenstam, Ragnhild Nilsson, and Jo Saglie. 2017. "Ett folk, ulike valg. Sametingsvalg i Norge og Sverige." In. Oslo: Gyldendal Akademisk.

Josefsen, Eva, Ulf Mörkenstam, and Jo Saglie. 2015. "Different institutions within similar states: The Norwegian and Swedish Sámediggis." Ethnopolitics 14 (1):32-51.

Josefsen, Eva, and Eli Skogerb $\varnothing$. 2013. "Indigenous democracy - media use and media coverage of the 2009 Sami parliamentary election campaign." Arctic Journal of Law and Politics 4 (1):6289. doi: http://site.uit.no/arcticreview/.

Karppinen, Kari, and Hallvard Moe. 2012. "What we talk about when we talk about document analysis." In Trends in Communication Policy Reseach: New Theories, Methods and Subjects, edited by Natascha Just and Manuel Puppis, 177-193, Bristol UK / Chicago, USA: Intellect.

Kvale, Steinar, and Svend Brinkmann. 2009. Interviews. Learning the craft of Qualitative Research Interviewing. Second ed. ed. Los Angeles: Sage.

Lantto, Patrik, and Ulf Mörkenstam. 2015. "Action, Organisation and Confrontation: Strategies of the Sami Movement In Sweden during the Twentieth Century." In Indigenous Politics: Institutions, Representation, Mobilisation, edited by Mikkel Berg-Nordlie, Jo Saglie and Ann Sullivan, 135-63. Colchester: ECPR Press.

Lehtola, Veli-Pekka. 2004. The Sámi People. Traditions in Transition. Fairbanks: The University of Alaska Press.

Markelin, Lia, and Charles Husband. 2013. "Contemporary dynamics of Sámi media in the Nordic States." In Media International Australiay, 70-81.

McCallum, Kerry, and Lisa Waller. 2017. The Dynamics of News and Indgenous Policy in Australia. Bristol: Intellect.

Moring, Tom. 2007. "Functional Completeness in Minority Language Media." In Minority Language Media: Concepts, Critiques and Case Studies, edited by Mike Cormack and Niamh Hourigan, 17-33. Clevedon: Multinlingual Matters.

Pettersen, Torunn. 2014. "Sámi ethnicity as a variable. Premises and implications for populationbased studies on health and living conditions in Norway." PhD-thesis, The Arctic University of Norway.

Pietikäinen, Sari. 2008. "'To breathe two airs": Empowering Indigenous Sámi media." In Global indigenous media: cultures, poetics, and politics, S. [197]-213. Durham: Duke University Press.

Plaut, Shayna. 2014. "Nation-building, not "Resistance Radio". Self Determination, the State \& Saami Media." Nordicom Review 35 (1):81-97.

- - . 2017. "Reshaping the Borders of Journalism." Journalism Practice 11 (1):1-32. doi: 10.1080/17512786.2015.1092391.

Rokkan, Stein. 1966. "Norway: Numerical democracy and corporate pluralism." In Political opposition in Western democracies, edited by Robert A. Dahl, 70-116. New Haven: Yale University Press.

Ross, Tara. 2017. "Rethinking Journalism and Culture." Journalism Studies 18 (12):1559-75. doi: 10.1080/1461670X.2016.1146626.

Schudson, Michael. 2008. Why democracies need an unlovable press. Cambridge: Polity.

Shohat, Ella. 1998. "Talking Visions: Multicultural Feminism in a Transnational Age." In. New York: MIT Press.

Skogerb $\varnothing$, Eli. 2001. "Sami Media - Identity Projects in a Changing Society." In Black Marks: Minority Ethnic Audiences and Media, edited by Karen Ross and Peter Playdon, 157-75. Aldershot: Ashgate.

Skogerb $\varnothing$, Eli, and Emma Kristine Sjøenden Vestli. 2016. "Sametingsvalet i SR Sameradion och SVT Sápmi." In Sametingsval. Väljare, partier och media, edited by Ragnhild Nilsson, Stefan Dahlberg and Ulf Mörkenstam, 247-267, Stockholm: Santérus. 
Syvertsen, Trine, Gunn Enli, Ole J. Mjøs, and Hallvard Moe. 2014. The Media Welfare State: Nordic Media in the Digital Era. Ann Arbor: The University of Michigan Press. 